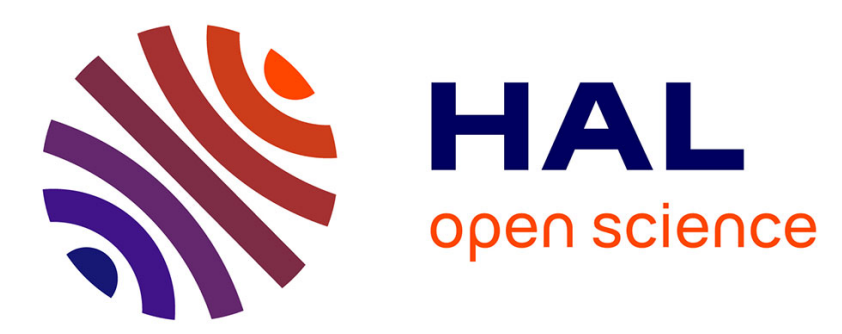

\title{
Iron dynamics in the rhizosphere as a case study for analyzing interactions between soils, plants and microbes
}

Philippe P. Lemanceau, Petra Bauer, Stephan Kraemer, Jean-François Briat

\section{To cite this version:}

Philippe P. Lemanceau, Petra Bauer, Stephan Kraemer, Jean-François Briat. Iron dynamics in the rhizosphere as a case study for analyzing interactions between soils, plants and microbes. Rhizosphere: achievements and challenges, 104, Springer Science + Business Media B.V., 536 p., 2010, Developments in Plant and Soil Sciences, 978-90-481-2855-6. hal-02824519

\section{HAL Id: hal-02824519 \\ https://hal.inrae.fr/hal-02824519}

Submitted on 6 Jun 2020

HAL is a multi-disciplinary open access archive for the deposit and dissemination of scientific research documents, whether they are published or not. The documents may come from teaching and research institutions in France or abroad, or from public or private research centers.
L'archive ouverte pluridisciplinaire HAL, est destinée au dépôt et à la diffusion de documents scientifiques de niveau recherche, publiés ou non, émanant des établissements d'enseignement et de recherche français ou étrangers, des laboratoires publics ou privés. 


\section{Yves Dessaux \\ Philippe Hinsinger Philippe Lemanceau}

Editors

\section{DEVELOPMENT IN PLANT AND SOIL SCIENCES 104}

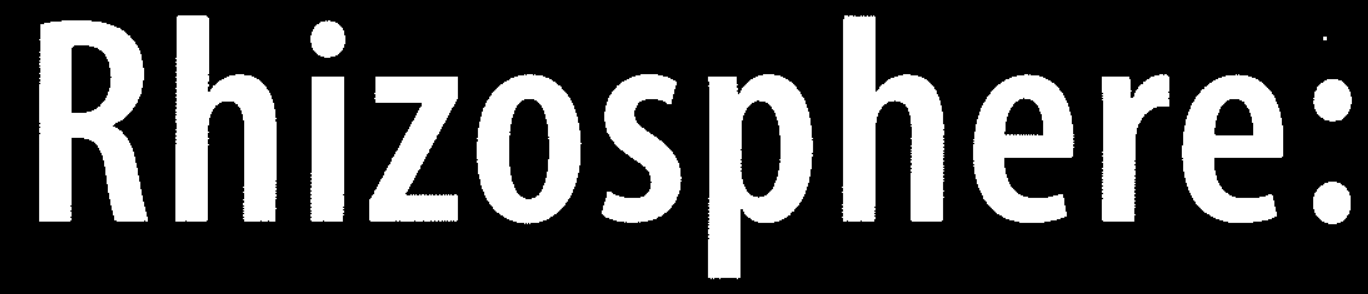

Achievements

and Challenges

i.

4.

Springer 
Development in Plant and Soil Sciences 104

Yves Dessaux

Philippe Hinsinger

Philippe Lemanceau

Editors

Rhizosphere: Achievements and Challenges

Described by Hiltner over a century ago (1904), the rhizosphere is defined as the fraction of soil influenced by plant root activities. 'This dynamic, complex interface where soil, plant roots and microbes interact is a major hotspot of microbial activity, where numerous subtle molecular processes, as well as multiple feedback events take place, Rhizosphere investigations at the microscopic scale have driven spectacular academic advances in the fields of soil sciences or plant-microbe interactions. They bear promises in terms of environmentally-friendly procedures such as bioremediation or ecological engineering. The long recognized role of rhizosphere processes in plant mutrition and health, and more generally in plant adaptation to stress conditions, is now becoming central for designing sustainable mamagement practices of agricultural and forest ecosystems. The rhizosphere, however, must also be considered and investigated at a much harger scale than its own, especially as a location where important steps of both carbon and nitrogen cycles occur, with obvious links with global changes. Major advances in understanding the rhizosphere have been achieved over the last two decades. Combined expertise in plant biology, microbial ecology and soil sciences and design of research strategies including the latest innovative methods in these fields opens exciling prospects for the future.

Reprinted from Plant and Soil, Vol. 321, nos 1-2

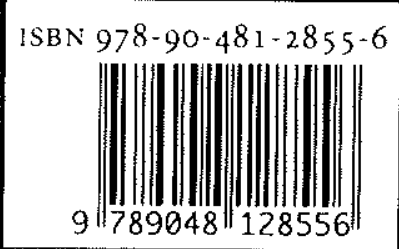

> springer.com 
Yves Dessaux $\cdot$ Philippe Hinsinger $\cdot$ Philippe Lemanceau Editors

\section{Plants and Soil}

Reprinted from Plant and Soil, Vol 321, nos 1-2.

\section{Springer}




\section{Editors}

Yves Dessaux

CNRS, Inst. Sciences due Vegetal (ISV)

avenue de la Terrasse,

91198 Gif-sur-Yvette, France

Philippe Hinsinger

INRA - SupAgro, UMR 1222 Biogeochimie du,

Sol et de la, Rhizosphere, place Viala,

34060 Montpellier, France

Philippe Lemanceau

Université Bourgogne, INRA-CMSE,

UMR 1229 Microbiologie du, Sol et de,

21065 Dijon, France

\section{Cover caption:}

Background photograph: Fababean (Vicia faba L.) grown in the long-term P-fertilizer field trial at Aúzeville (INRA Toulouse), exhibiting roots with $\mathrm{N}_{2}$-fixing nodules, abundant roots hairs and adhering soil, i.e. key players and features in the rhizosphere of legumes (photograph by P. Hinsinger).

Left insert photograph: In situ detection of gfp-tagged Pseudomonas sp. DSMZ 13134 cells on root surface of barley (Hordeum vulgare L.) using the CLSM (confocal laser scanning microscope LSM510, Carl Zeiss, Jena, Germany). Two-day old seedlings were inoculated with a bacterial suspension ( $10^{8}$ cells per seedling). Plants were grown for two weeks in agricultural soil in pots in a greenhouse before analysis of the root colonization. Autofluorescent soil particles can be seen in the upper right comer (courtesy of K. Buddrus-Schiemann, Helmholtz Zentrum München, Neuherberg, Germany).

Right insert photograph: In situ detection of bacterial cells on the root surface of potato (Solanum tuberosum L.) grown under field conditions four weeks after planting. Fluorescence in situ hybridization (FISH) was performed using the oligonucleotide probe EUB-338-mix labeled with Fluos. Bacterial cells appear with the CLSM as green fluorescent signals and a clay particle can be seen as redish autofluorescence (courtesy of K. Buddrus-Schiemann, Helmholtz Zentrum München, Neuherberg, Germany).

\section{DOI: $10.1007 / 978-90-481-2857-0$}

Library of Congress Control Number: 9789048128556

(1) Springer Science + Business Media B.V., 2010

No part of this work may be reproduced, stored in a retrieval system, or transmitted

in any form or by any means, electronic, mechanical, photocopying, microfilming, recording

or otherwise, without written permission from the Publisher, with the exception

of any material supplied specifically for the puipose of being entered

and executed on a computer system, for exclusive use by the purchaser of the work.

Printed on acid-free paper

springer.com 


\section{Contents}

\section{Editorial}

Rhizosphere: so many achievements and even more challenges

Y. Dessaux $\cdot$ P. Hinsinger $\cdot$ P. Lemanceau

\section{Review Articles}

Carbon flow in the rhizosphere: carbon trading at the soll-root interface D.L. Jones · C. Nguyen · R.D. Finlay

Nitrogen-fixing bacteria associated with leguminous and non-leguminous plants

C. Franche $\cdot K$. Lindström $\cdot$ C. Elmerich

Blochemical cycling in the rhizosphere having an impact on global change

L. Philippot · S. Hallin · G. Börjesson · E.M. Baggs

Plant-microbe-soll interactions in the rhizosphere: an evolutionary perspective

H. Lambers · C. Mougel · B. Jaillard · P. Hinsinger

Rhizosphere: biophysics, biogeochemistry and ecological relevance

P. Hinsinger - A.G. Bengough - D. Vetterlein - I.M. Young

Plant root growth, archltecture and function

A. Hodge - G. Berta - C. Doussan · F. Merchan - M. Crespi

The rhizosphere zoo: An overview of plant-associated communities of microorganisms, including phages, bacteria, archaea, and fungl, and of some of their structuring factors M. Buée - W. De Boer - F. Martin - L. van Overbeek - E. Jurkevitch

Rhizosphere fauna: the functional and structural diversity of intimate interactions of soll fauna with plant roots

M. Bonkowski $\cdot$ C. Villenave $\cdot$ B. Griffiths

Piant-driven selection of microbes
A. Hartmann ' M. Schmid .
D. van Tuinen
G. Berg

Rhizosphere microblota interfers with plant-plant interactions

A. Sanon - Z.N. Andrianjaka - Y. Prin · R. Bally - J. Thioulouse ·

G. Comte $\cdot R$. Duponnois

Molecular communication in the rhizosphere

D. Faure $\cdot$ D. Vereecke $\cdot$ J.H.J. Leveau

Acquisition of phosphorus and nitrogen in the rhizosphere and plant growth promotion by microorganisms

A.E. Richardson - J.-M. Barea - A.M. McNeill - C. Prigent-Combaret

The rhizosphere: a playground and battlefield for sollborne pathogens and beneficlal microorganisms

J.M. Raaljmakers - T.C. Paulitz · C. Steinberg · C. Alabouvette · Y. Moënne-Loccoz

Rhizosphere engineering and management for sustainable agriculture

P.R. Ryan - Y. Dessaux - L.S. Thomashow - D.M. Weller

Rhizosphere processes and management in plant-assisted bioremediation

(phytoremediation) of soils

W.W. Wenzel 
Novel approaches in plant breeding for rhizosphere-related traits M. Wissuwa - M. Mazzola - C. Picard

Strategles and methods for studying the rhizosphere-the plant sclence toolbox G. Neumann - T.S. George - C. Plassard

Sampling, defining, characterising and modeling the rhizosphere-the soil science tool box

J. Luster · A. Göttlein - B. Nowack - G. Sarret

Molecular tools in rhizosphere microbiology-from single-cell

to whole-community analysis

J. Sørensen - M. Haubjerg Nicolaisen - E. Ron - P. Simonet

$483-512$

Iron dynamlcs in the rhizosphere as a case study for analyzing Interactions between solls, plants and microbes

P. Lemanceau - P. Bauer - S. Kraemer - J.-F. Briat 